\title{
THE INFLUENCE OF URBAN SPRAWL ON THE GEO-DEMOGRAPHIC DYNAMICS OF PERIURBAN RURAL SPACE. CASE STUDY ON THE POST- SOCIALIST EXPANSION OF SUCEAVA CITY
}

DOI: http://dx.doi.org/10.18509/GBP.2016.49

UDC: 314(497.113)

\section{PhD. Anamaria Ioana Tomașciuc}

Prof. PhD. Corneliu Iațu

Alexandru Ioan Cuza University of Iasi, Faculty of Geography and Geology, Department of Geography, Bd. Carol I 20A, 700505, Iasi, Romania

\begin{abstract}
In order to create a real image of the urban sprawl in post-communist cities, we must exceed the administrative boundaries of the city and analyse the geo-demographic changes of the rural area located in proximity, which faces consequences of diffuse urban development. In Romania, from a demographic point of view, periurban areas are the most dynamic areas of the country, the main cause being the migration, not the natural growth. Suceava City, located in the North-East Development Region of Romania, is representative for the studied issue, being, in terms of spatial dynamics, in a process of urban sprawl. The population of the communes included in the periurban area of Suceava City, increased by about 10.000 people in the period between 1992 and 2011 censuses. Our study used GIS techniques, having as support multi-temporal cartographic materials, such as topographic plans and ortophotoplans, and a dynamic study area, to demarcate the penetration of urban expansion in periurban space and to highlight the influence of urban sprawl on the rural space located in vicinity.
\end{abstract}

Keywords: urban sprawl, periurban space, Suceava City, post-socialist.

\section{INTRODUCTION}

The spontaneous, uncontrolled expansion of urban space has become a topical issue that Europe faces nowadays, even under minimal pressure from the population, existing several adjacent factors that trigger this phenomenon [1].

The issue of spatial development of Romanian cities is a topic debated by researchers in the past, but also a highly up-to-date theme, in the context of urban spatial dynamics specific to the post-socialist period. Recent studies focus on urban transformations occurred after changing the political regime, and with it, the economy and people's mentality. People began to migrate in areas located in the proximity of the city, in individual dwellings, at the expense of collective dwellings specific to the urban space. The changes and transformations specific to the post-socialist period represent the analysis subject for other researchers, studying areas belonging to the former communist bloc states [2].

The phenomenon of urban sprawl is described by the European Environment Agency, as a pattern of urban expansion, especially to rural areas close to the city, predominantly on agricultural land, characterized by a low density of built-up space. Spontaneous 
expansion involves a low degree of planning and an uneven, diffuse development with a tendency of discontinuity [3]. Periurban areas can be considered an "output" of the phenomenon of urban sprawl [4].

In Romania, urban expansion is not caused by the pressure exerted by population. The triggering factor of the phenomenon is the desire of inhabitants for a new living environment, outside the city, in the periurban space. Urban sprawl was accelerated by the development of transport infrastructure, and thus by increasing the population's mobility, through the accessibility offered to the middle-class for periurban areas [5].

The total population of Romania is decreasing in the past 25 years, periurbanization being the main phenomenon that generates positive demographic evolution at local level. The Romanian periurban space consists of rural-urban transitional areas, which do not have a political and administrative perimeter and oscillate between keeping their traditional identity and integrating in urban area [6]. Romania's integration in the European Union has accelerated this process, emphasizing the new interfaces occurred at the contact area of large cities with surrounding communities [7].

In this study, periurbanization is perceived as being the current evolutionary phase of Suceava City and for this reason we highlighted the localities marked by the installation of the urban population on their territory, by including them in a limit, generically called periurban area.

The paper aims to use GIS techniques, having as support multi-temporal cartographic materials, such as topographic plans and ortophotoplans, and a dynamic study area, to demarcate the penetration of urban expansion in periurban space and to highlight the influence of urban sprawl on the rural space located in vicinity.

\section{STUDY AREA}

In terms of administration, the study area is located in the North-East Development Region of Romania, in the south-eastern part of Suceava County. Since the territorial evolution of Suceava City is a complex phenomenon whose influence is present outside the administrative boundaries, it is required a study area wide enough for assessing such a process.

The study area (Fig. 1) includes 9 administrative units: Suceava City and 8 LAU2 ${ }^{1}$ located in the vecinity, respectively Salcea City and 7 communes: Scheia, Ipotesti, Moara, Adancata, Mitocu Dragomirnei, Patrauti and Bosanci. The entire area covers a surface of $405 \mathrm{~km}^{2}$ and encompasses a population of 148.662 inhabitants, of which 92.121 (62\%) are living in Suceava City. (REC, 2011)

In terms of spatial dynamics, Suceava City is in a process of urban overflow, and its population is decreasing since 1992, and more pronounced after 2002. The negative trend is caused by three main factors: negative natural growth, emigration and migration to periurban area. The last is the most important, the main argument being the high number of people who have chosen to leave collective dwellings located in the city, in favour of individual houses situated in periurban rural area [6].

The only commune that does not share any administrative boundary with Suceava City, but is still included in the periurban area is Bosanci, which by its spatial and demographic

\footnotetext{
${ }^{1}$ Local Administrative Unit
} 
dynamics, especially from the last decade, justifies its presence alongside the others periurban communes.

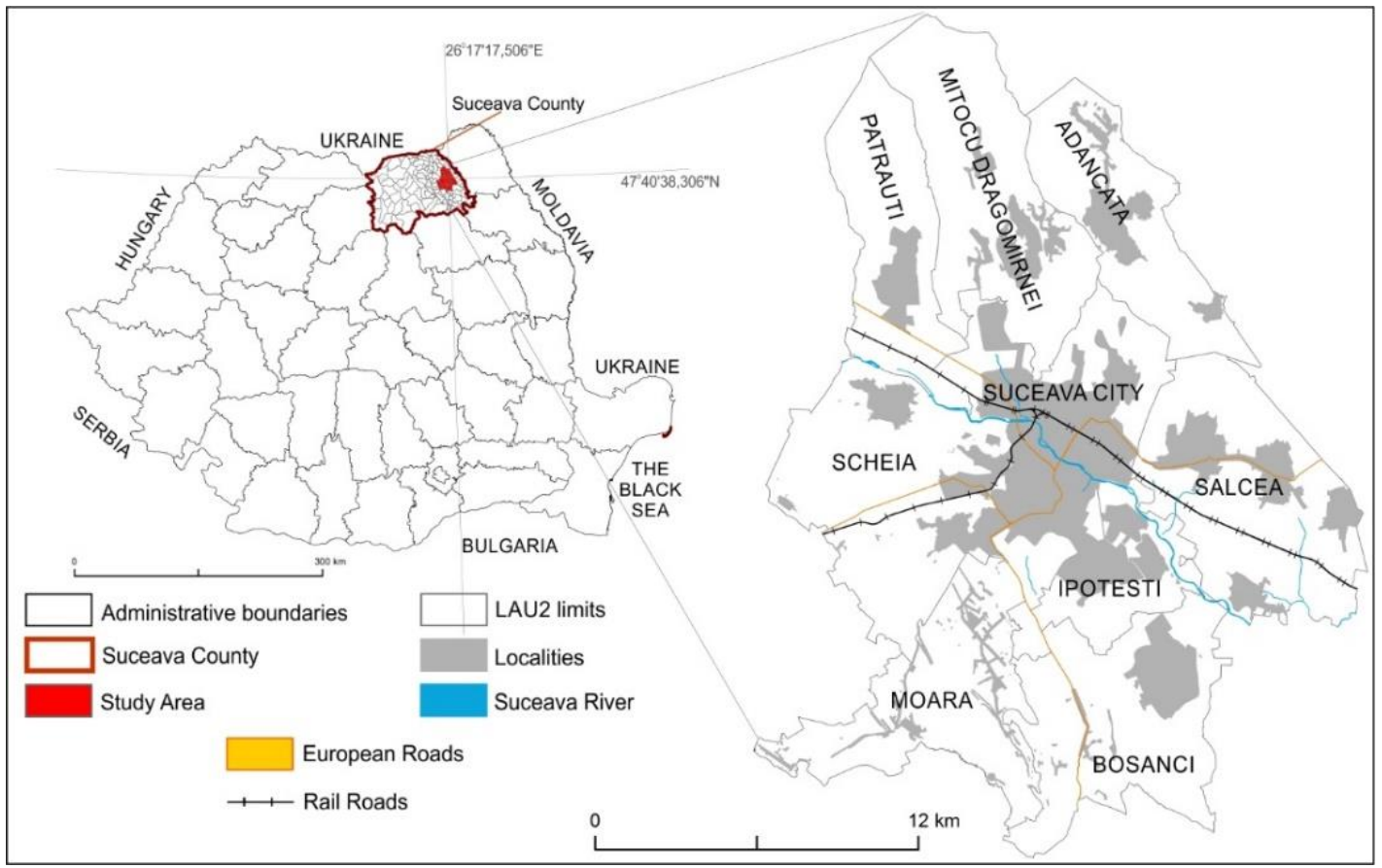

Figure 1. Geographical location of the study area Spatial data source: ANCPI 2012

\section{MATERIALS AND METHODS}

Throughout the paper were followed two directions of analysis, closely connected: spatial expansion of built-up space and numerical evolution of population. For the first directon were used multi-temporal cartographic materials, such as topographic plans, scale 1:5000 (around 1980) and ortophotoplans (2005 and 2012) available in ANCPI online portalviewer. Although our study covers the post-socialist period, the plans made in the 80 's are relevant, because in the period ' 80 - $^{-} 90$ there were no major constructions in the periurban space. The thematic layers comprising the built-up space were completed and updated, using vectorial data provided by geo-spatial.org community [8] (drawn using 30 plans, scale 1:5 000, which cover the area occupied by Suceava City and its surroundings) and used to demarcate the penetration of urban expansion in periurban space. Although for the analysis were used three temporal thresholds of reference (1980, 2005 and 2012), for the expansion map were used only two of them $(1980,2012)$ to emphasize the phenomenon of urban sprawl. Data were processed and analysed using ArcGis software. For analysing the situation from a demographical point of view, were considered the available data from 1992, 2002 and 2011 censuses [9]. The analysis was conducted at local level, for all 9 administrative units included in the study area.

\section{RESULTS AND DISCUSSION}

In order to place the expansion of Suceava City in a territorial and temporal context, it is important to follow the development of settlements' network, in terms of spatial dynamics and in terms of geo-demographical evolution. 


\section{Spatial expansion - in administrative boundaries}

After the documentary attestation in 1388, the territorial evolution of Suceava City manifested in many forms, in terms of typology: agglutinative development (XIV - XVIII centuries), tentacular evolution by absorbing the surrounding localities (XVIII - XIX centuries), polynuclear expansion through development of the satellite localities, Itcani and Burdujeni and planned development, dictated by the political regime $(1900-1989)$ [10] [11]). In post-communist period, the territorial expansion of Suceava City (Fig. 2) is very pronounced, with an uncontrolled, diffuse character. Thus, there are generated new residential areas, with lower density of built-up space than compact areas specific to the city.

In the early 90s, Suceava expanded its territory by partial absorption of Sfantu Ilie Village from Scheia Commune, which was later transformed in the district of apartment buildings, Obcini. The post-communist period is outlined through the decline of industrial areas, many of them being demolished and reconverted gradually in shopping areas (eg. the placement of Iulius Mall and Suceava Shopping City patronized by Carrefour in the industrial area „Suceava Valley”). In terms of commercial areas there was a real „boom” in Suceava, most of them developing on the fluvial terrace of Suceava's floodplain (Selgros hypermarket, Duo Mat, Dedeman, Saturn) and along the European road E85, at the exit to Falticeni / Bucharest (Metro hypermarket, Primagra Center, car dealerships, many hotels and restaurants). At the exit to Radauti/Siret from Itcani, along the E85 road and along E58 road that connects Suceava to Botosani City, the development of commercial areas is less present.

Another manifestation form of urban sprawl is represented by the occurrence of residential areas similar in appearance and functionality with those developed in the periurban space. The most important and homogeneous residential areas of this kind were developed in Burdujeni, at the north of Gheorghe Doja Street. On a larger surface area, extends the residential space located between Burdujeni and Itcani districts, at the north of the European road E58. Another dynamic residential area is located at the boundary with Ipotesti Commune, at the west of 208A county road, but it was recently transfer in the administration of Ipotesti Commune. On the left side of the european road, at the exit to Botosani, near the boundary with Salcea, is developing a large residential complex, which benefited from substantial investments in infrastructure, having a very modern road network.

The evolution of housing stock in Suceava in the perioad 1990-2012 was strongly ascending, with a pronounced increase in 2008. This real estate „boom” in 2008 is a consequence of the investments made in the period before the financial crisis, the effects of recession being slightly concealed.

The expansion of built-up area extended beyond the administrative boundaries of Suceava, in the surrounding communes. 


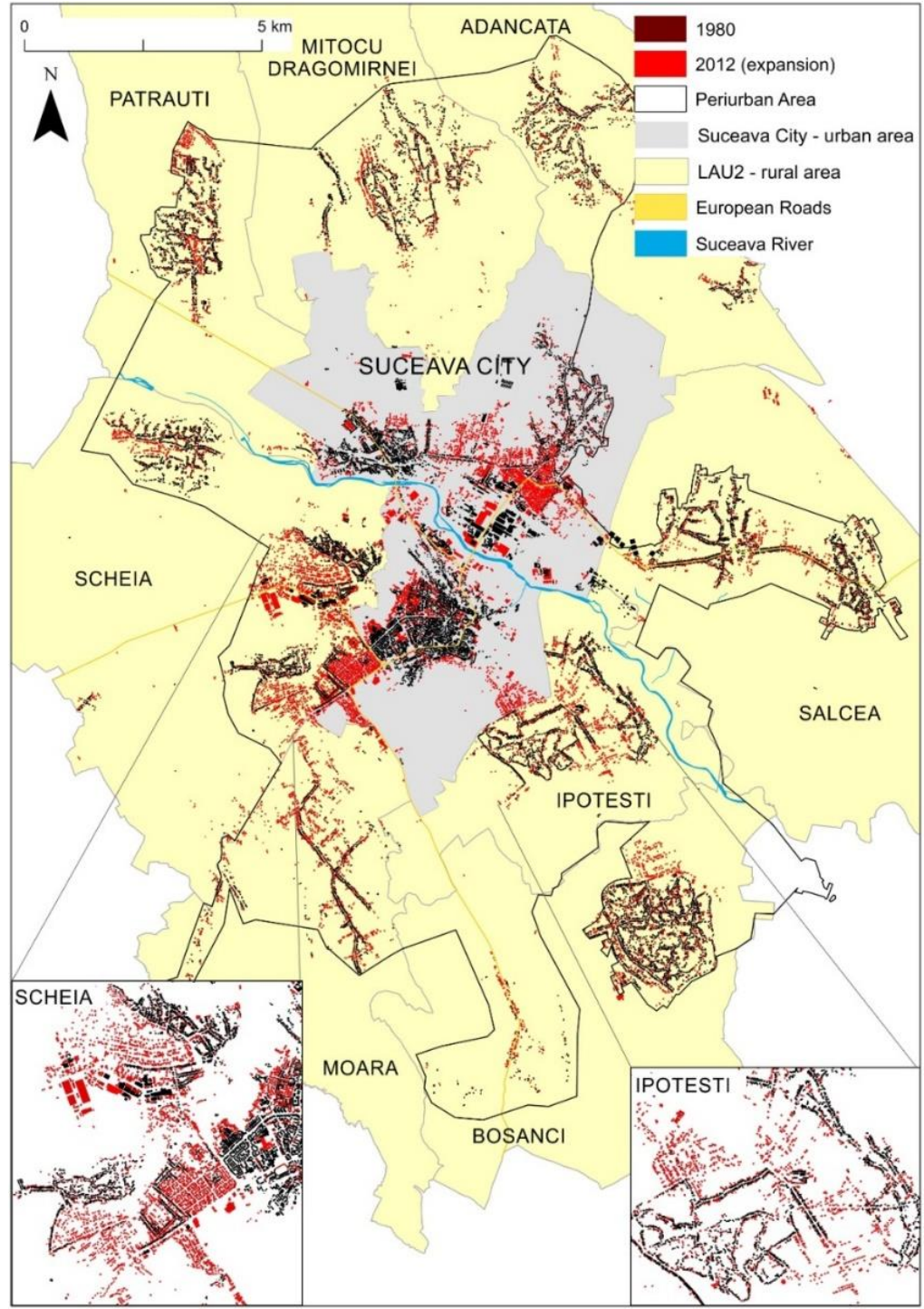

Figure 2. Spatial expansion of built-up area in Suceava City and its proxim rural space (1980-2012)

Spatial data source: ANCPI 2012, geospatial.org, Statistical data source: Censuses of 1992, 2002, 2011

\section{Spatial expansion - outside the administrative boundaries}

Before 1990, the territorial expansion of localities was caused mainly by a natural evolution, directly related to population growth and planned constructions made during the iron curtain. In the post-decembrist period the spatial extension of localities is generated by other processes and in a different social context. Natural dynamics of population is rather stagnant or even negative, the expansion of built-up space from rural localities and the increase of population number being fuelled by the periurbanization process. The large surfaces occupied by new residential areas are the result of an unstructured, space consuming, spontaneous expansion, where everyone builds on his own, without taking into account future development directions. In this way are created incoherent residential spaces, whose functionality is often marked by the lack of initial unitary planning. 
The main directions of expansion are in the west, southwest, south, southeast (Fig. 2), distinguishing a growth ring around the city, the localities from Scheia Commune (Scheia and Sfantu Ilie) and Ipotesti (Ipotesti and Lisaura) creating a continuous space at the contact with the administrative limit of Suceava City.

Table 1. Typological classification of the communes from Suceava's periurban space, considering the percentage of built-up surface evolution

Communes intensly influenced by periurbanization $(>40 \%) \quad$ Scheia

Communes strongly influeced by periurbanization (30- Moara, Ipotesti, Patrauti 40\%)

Communes moderately influenced by periurbanization (20- Salcea, Bosanci $30 \%)$

Communes slightly influenced by periurbanization $(<20 \%) \quad$ Mitocul Dragomirnei, Adancata

In Scheia commune, besides the classic residential periurban space, are very well developed the commercial periurban areas, over 500 companies being based in the commune, including two well known hypermarkets (Real and Lidl). According to local authorities, attracting companies in the territory of the commune is one of the objectives proposed in the development strategy of the commune. The main factors that favour and encourage the development of these periurban areas from Scheia are the proximity to the city, the presence of the European road (E58) and the possibility to connect to all public utilities (water, sewerage, gas, electricity, etc.).

In Ipotesti and Moara communes dominates the residential periurban area (the commercial areas are less present in the periurban space), the main factors favouring the expansion of these spaces being the proximity of the city (especially in the case of Ipotesti commune, which is located only a few minutes from the city center), the presence of public utilities, and also the quality of the environment, which creates a favourable living space.

\section{Demographic dynamics}

At the 2011 census, the population of Suceava City and its periurban space encompassed 148.662 inhabitants. If we take into consideration Suceava City, whose population is declining in the last two decades, the trend of population is negative. But, if we consider only the rural localities from the periurban area, the population trend is ascending (from 46.765 inhabitants registered in the 1992 census to 56.541 inhabitants registered in the 2011 census).

According to statistical data, the population of Suceava City is decreasing in the last two decades, from 114.462 inhabitants in 1992 to 92.121 inhabitants in 2011 (Fig. 3). The decline of population is not as dramatic as the statistical data shows, if we take into account the evolutive stage of Suceava, respectively, the periurbanization. The urban population that opted for individual housing in rural areas is still dependent of urban areas, both through the workplace and through specific urban facilities that cannot be equalled by periurban communes. However, during the period 1992-2011 the population of periurban area increased with 10.776 inhabitants. If we consider that this increase is mainly caused by urban migration in rural areas, would mean that the population of Suceava is actually about 102.000 inhabitants, number located under the 105.865 inhabitants registered at the previous census in 2002. Although partially masked by periurbanization, the population decline of the city is still very real. 
Among the communes located in the periurban area, are distinguished the ones where population increased by more than 1.000 inhabitants between 1992-2011, such as: Scheia $(+5.110)$, Moara (+1.336), Salcea (+1.061), Patrauti (+1.044) and Ipotesti (+1.009). In Scheia, the periurbanization process is the most visible, this phenomenon having on its territory the most complex forms of manifestation.

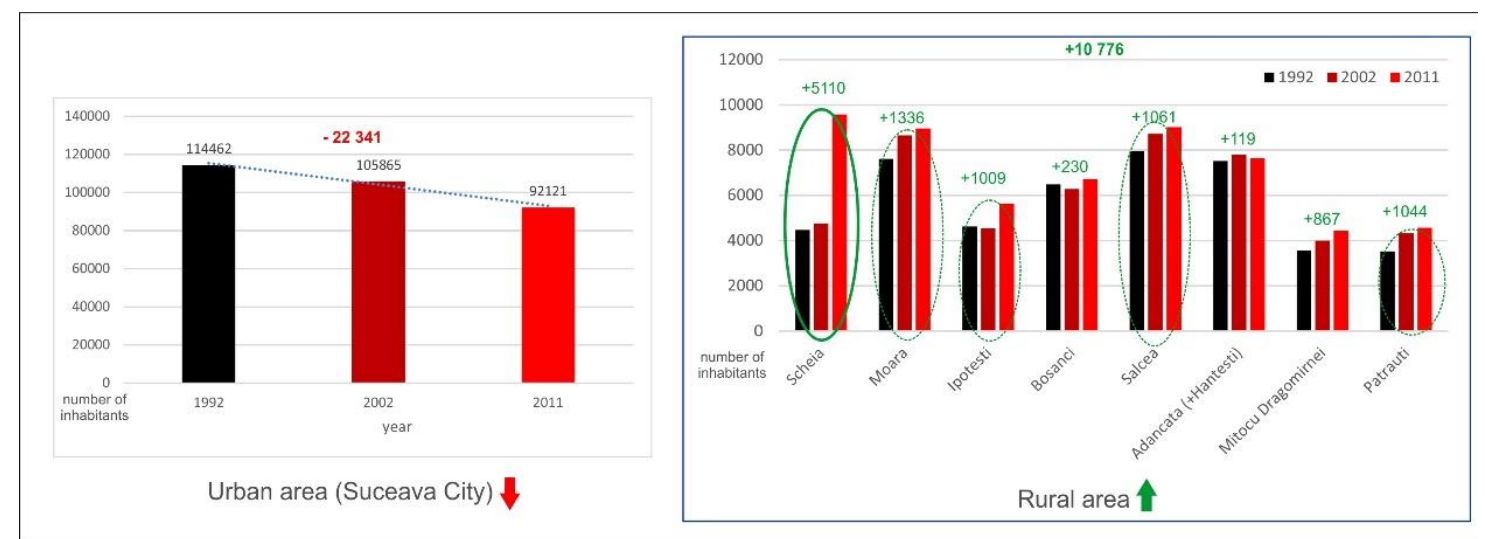

Figure 3. Dynamics of population number in urban and rural areas (1992-2011) Statistical data source: Censuses of 1992, 2002 and 2011

\section{CONCLUSIONS}

Suceava City tends to expand to the south-west, south and south-east, the proximity to the city being one of the main triggering factors that determine the attractiveness of the rural localities for urban migration.

The spatial development of periurban area is much more accelerated compared to population dynamics, becoming more space consuming, due to the diffuse character of territorial expansion. In Scheia, and the other communes as well, there are all the premises for continuing the sustained process of spatial development from the last decades.

A major challenge for the actors involved in spatial planning at the local level, consists in minimizing the negative effects of periurbanization and maximizing the benefits for both rural areas whose territories are changed by the installation of urban population and for people living in the new residential areas from the periurban space. Studies regarding the complex process of periurbanization could represent for local authorities both an instrument and a starting point in this direction.

\section{REFERENCES}

[1] Suditu B., Urban sprawl - the legal context and territorial practices in Romania, Human Geographies Journal of Studies and Research in Human Geography, 6 (1), 2012, pp. 73-77.

[2] Dimitrov S., Todorova E., The spatial „response” of the transition: the case of Bulgaria, International Scientific Conference Geobalcanica 2015, Republic of Macedonia, 2015, pp. 451-456.

[3] EEA Report, Urban sprawl in Europe - The ignored challenge, No. 10, 2006.

[4] European Region Planning, Definition and measurement of the factors that cause urban expansion and their influence on each other, Council of Europe, Strasbourg, 1979.

[5] Warf B., Encyclopedia of Human Geography, Sage Publications, Inc., Florida State University, 2006. 
[6] Tomasciuc A.I., Eva M., Iatu C., Mechanisms of territorial governance in postsocialist periurban areas from the perspective of local public authorities. A case study on localities from proximity of Suceava City (Romania), Papers of Geographic Seminar „Dimitrie Cantemir”, No. 39(1), Romania, 2015, pp. 73 - 86.

[7] Ianos I., Cercleux A.L., Pintilii R.D., Remarks on identity building of rural and urban communities in the Bucharest Metropolitan Area, Annals of the University of Oradea, Tom XX, No. 2, Romania, 2010, pp. 173-183.

[8] Craciunescu V., Antoci A., 2008, http://www.geo-spatial.org/download/seturi-dategeospatiale-locale

[9] National Institute of Statistics, REC 1992, „The final results of the 1992 Population and Housing Census", http://colectaredate.insse.ro/phc/public.do?siteLang=ro, REC 2002, „Final results of the 2002 Population and Housing Census”, http://www.insse.ro/cms/files/rpl2002rezgen1/rg2002.htm, REC 2011, „Final results of the 2011 Population and Housing Census", http://www.recensamantromania.ro/rezultate-2/.

[10] Matei M.D., Contributii arheologice la istoria orasului Suceava (Archaeological contributions to the history of Suceava, 1961, Romania, Published by Editura Academiei Republicii Populare Romania.

[11] Ungureanu A., Orasele din Moldova - studiu de geografie economica (The cities of Moldova - study of economic geography), 1980, Romania, Published by Editura Academiei Republicii Socialiste. 